\title{
THE FORMATION OF AUTHORITIES OF THE SOVIET SOCIALIST REPUBLIC OF LITHUANIA AND BELARUS ON THE EXAMPLE OF THE PEOPLE'S COMMISSARIAT FOR HEALTH CARE AT THE BEGINNING OF 1919
}

\author{
Alexey A. Kapliyev \\ (National Academy of Sciences of Belarus, Institute of History)
}

\begin{abstract}
The article presents an analysis of the formation and activity of the People's Commissariat for Health Care of the Socialist Soviet Republic of Lithuania and Belarus at the beginning of 1919. The basic structure of the Commissariat was worked out on the basis of various sources. It was found that, due to the outbreak of the 1919-1921 Polish-Soviet war, the efficiency of the Commissariat during its time in Vilnius was limited. The relative stabilisation of the health-care management system was achieved after the Commissariat was evacuated to Minsk, and later to Bobruisk, away from the front line. It has been proven that at the beginning of the Polish-Soviet war, military and civil medical care was combined in a single system, and all medical professionals in the Lithuanian-Belarusian Soviet Republic were required to do military service. The worsening of the military situation for the Red Army in Lithuania and Belarus determined the split of the Health Care Commissariat into two separate divisions: the field division for medical care for Soviet troops near the front line, and the civil division for helping civilians.
\end{abstract}

KEYWORDS: Socialist Soviet Republic of Lithuania and Belarus, People's Commissariat for Health Care, epidemics, medicine.

\section{Introduction}

The organisation of a health-care management system during the extraordinary conditions of war, revolution, epidemics, and so on, is seldom studied but simultaneously topical as a research subject for historians, especially nowadays. After the October Revolution in 1917, the new Bolshevik authorities faced chaos at almost every level of the state system, including health-care. The situation was complicated by the absence of a central management body for medicine in the former Russian Empire, so the Bolsheviks had neither special experience nor an 'institutional heritage' in medical 
management business, and faced a need to develop health-care from scratch. The situation was made worse by the increased occurrence of epidemic diseases, which was a consequence of the First World War between 1914 and 1918, the unstoppable waves of refugees who lived in unhygienic conditions with few medicines, and the collapse of the network of medical institutions. The same problems were inherent in the Bolshevik-created Soviet republics, including the Socialist Soviet Republic of Lithuania and Belarus (called LitBel). Despite the many studies on LitBel that were prepared in the Soviet period and later, there is still no research about the health-care system in the Lithuanian-Belarusian Socialist Soviet Republic. ${ }^{1}$ This article analyses the formation of the LitBel People's Commissariat for Health Care at the beginning of 1919.

\section{The establishment of the Soviet Socialist Republic of Lithuania and Belarus}

After the October Revolution in 1917, the Bolsheviks formally declared freedom for all former nations of the Russian Empire, but their expansionist policy and course towards world revolution led to conflicts with several newly formed neighbouring countries, Finland, Poland, Ukraine and the Baltic States. ${ }^{2}$ After the end of the First World War and the withdrawal of the German army at

${ }^{1}$ V. Micel'maheris, Ocherki istorii mediciny v Litve (Avtoreferat dis. dokt. med. nauk, 1964), p. 14; B. Vaitkevičius, Socialistinè revoliucija Lietuvoje 1918-1919 metais (Vilnius, 1967); E. Shkljar, Bor'ba trudiashhihsja Litovsko-Belorusskoi SSR s inostrannymi interventami i vnutrennei kontrrevoljuciei (1919-1920 gg.) (Minsk, 1962); A. Cihamiraŭ, 'Litoŭska-Belaruskaja Saveckaja Sacyjalistychnaja Respublika, in: Encyklapiedyja historyi Bielarusi Vol. 4 (Minsk, 1997); Istorija gosudarstva i prava Belorusskoj SSR, Vol. 1 (1917-1936 gg.), ed. S. Margonski et al. (Minsk, 1970); A. Eidintas, V. Žalys, A. Senn, Lithuania in European Politics: The Years of the First Republic, 1918-1940, ed. E. Tuskenis (New York, 1998); A. Vabishchevich et al., Historyja Bielarusi, Vol. 5: Bielarus' u 1917-1945 hh., ed. M. Kasciuk (Minsk, 2007); Č. Laurinavičius, 'Once Again on Soviet Statehood in Lithuania in 1918-1919', in: Lithuanian Historical Studies, Vol. 13 (2008), pp. 179-19o; Historical Dictionary of Lithuania, 2nd Edition (Scarecrow Press, 2011); Organy gosudarstvennoi vlasti i upravleniia Sovetskoi Belarusi (1917-1920 gg.), ed. M.K. Bober et al. (Minsk, 2017); S. Boridczenko, 'Polityczno-etniczny aspekt kształtowania się wschodnich granic Republiki Białorusi w latach 1918-1924', in: Studia z dziejów Rosji i Europy Środkowo-Wschodniej, Vol. 54, No 2 (2019), pp. 129-149.

${ }^{2}$ Dekrety Sovetskoi vlasti. Vol. I. 25 oktiabria 1917 g. - 16 marta 1918 g. (Moskva, 1957), pp. 39-41; Kommunisticheskaia partiia Sovetskogo Soiuza v rezoliuciiah i resheniiah 
the end of 1918, the most dangerous enemy of the Bolsheviks to the west was Poland, whose leader Joseph (Józef) Piłsudski was eager to restore the former borders of the Polish Commonwealth (the Rzeczpospolita), which meant taking part of Belarusian, Lithuanian and Ukrainian lands. ${ }^{3}$ To prepare for a possible conflict with new enemies on its Western front, and to show the world the statehood-creating possibilities for nations of the former Russian Empire, several Soviet quasi-states (Belarus, Lithuania, Ukraine, etc) were created as a buffer between Soviet Russia and the West.

The Lithuanian and Belarusian Soviet republics were created almost simultaneously (16 December 1918 and 1 January 1919 respectively), based on the example of Soviet Russia, and were similar according to the reasons for their creation and the temporary character of their existence (their governments were only called 'provisional', and not a Council of People's Commissars, as in the Russian Socialist Federative Soviet Republic [RSFSR]). ${ }^{4}$ The governments were formed with the participation of local politicians, but were in fact fully controlled from Moscow. From almost the very moment of the creation of these republics, they were meant to be united into a single Soviet state, to prevent 'nationalism' both in Lithuania and Belarus, and to make a stronger barrier against Poland. ${ }^{5}$ Meanwhile, the battle for Lithuania and Belarus had begun. After the withdrawal of the German army, Polish troops took Vilnius on 1 January 1919, but the city was occupied by the Red Army five days later, and Vilnius became the capital of Soviet Lithuania.

The unification of the Lithuanian and Belarusian Soviet republics began on 16 January 1919, when the Central Committee of the Russian Communist Party, despite protests from the Belarusian

s'ezdov, konferencii i Plenumov CK (1898-1988). Vol. 2: 1917-1922, ed. A.G. Egorova, K.M. Bogoliubova (Moskva, 1983), pp. 290-291.

${ }^{3}$ J. Piłsudski, Pisma zbiorowe: wydanie prac dotychczas drukiem ogtoszonych. T. VII (Warszawa, 1937), p. 147 .

${ }^{4}$ V. Mickevich-Kapsukas, 'Revoliuciia v Litve (1918 g.) i sozdanie Vremennogo revoliucionnogo raboche-krest'ianskogo pravitel'stva', in: Istorik-marksist, No 2-3 (1935), pp. 44-52; Viestki Chasovaho Rabotnicha-Sielianskaho Radavaho (Sovietskoho) Uradu Bielarusi, No 1 (1919), p. 1.

${ }^{5}$ Zvezda, No 343 (1918), p. 1. 
Soviet government, decided to take the Mogilev and Vitebsk governorates away from the Belarusian SSR, and attach them to the RSFSR. ${ }^{6}$ Simultaneously, the governments of both the Lithuanian and the Belarusian SSR noted that political objectives and the international situation dictated the need for the unification of Belarus and Lithuania. ${ }^{7}$

Unification was formally announced at the beginning of February 1919 (only one month since the 'proclamation' [the exact wording] of the SSR of Belarus) during the First All-Belarusian Congress of Soviets (2 and 3 February 1919) and the First Congress of Soviets of Lithuania (18 to 20 February 1919). ${ }^{8}$ On 27 February 1919, a solemn meeting of the Central Executive Committees of the Belarusian SSR and the Lithuanian SSR was held in Vilnius, where the Presidium of the Central Executive Committee of LitBel, headed by Kazimir Tsekhovsky, was elected. The same session created the government of LitBel, which this time was not 'provisional', and was officially named the Council of People's Commissars, headed by Vincas Mickevičius-Kapsukas. ${ }^{9}$ The government consisted of People's Commissariats of Foreign Affairs, Internal Affairs, Education, Food, Labour, Finance, Justice, War, Communications, Agriculture, People's Economy, and Post. ${ }^{10}$ Thus there was no place for the Health Care Commissariat in the Council of People's Commissars at the beginning of the work of the LitBel government.

\section{The formation of the People's Commissariat for Health Care of LitBel}

The statehood of LitBel had mostly a propaganda character, and only formal trappings of an independent state. Due to this, part of the government, such as the Commissariats of Health Care and

\footnotetext{
${ }^{6}$ A. Vabishchevich et al., Historyja Bielarusi, pp. 108-109.

${ }^{7}$ B. Vaitkevičius, Socialistinè revoliucija Lietuvoje, p. 493.

${ }^{8}$ Zvezda, No 364 (1919), p. 3; A. Grickevich, Zapadnyifront RSFSR 1918-1920. Bor'ba mezhdu Rossiei i Pol'shei za Belorussiiu (Minsk, 2010), pp. 112-113.

${ }^{9}$ E. Shkljar, Bor'ba trudiashchikhsia Litovsko-Belorusskoi SSR, p. 35 .

${ }^{10}$ Bor'ba za sovetskuiu vlast'v Belorussii 1918-1920 gg.: Sb. dokumentov i materialov. In 2 vols. Vol. 2: Fevral' 1919 g. - 1920 g. (Minsk, 1971), p. 38; B. Vaitkevičius, Socialistiné revoliucija Lietuvoje, p. 499.
} 
Social Protection, was not a priority of the Bolsheviks, which shifted these duties to several departments of the Commissariat of Internal Affairs." Only at the session of the Council of People's Commissars from 28 February to 1 March 1919 were departments of Health Care and Social Protection withdrawn from the structure of the Commissariat of Internal Affairs, and converted to separate commissariats. ${ }^{12}$

Meanwhile, medical issues were critical: the rapid growth in refugees, who were carriers of infection, led to large epidemics that had to be stopped by the health-care authorities. These factors determined the need for the creation of a special supreme medical body, the People's Commissariat for Health Care, which was to be an exact copy of the same body in the RSFSR.

The Soviet health-care model was guaranteed and financed by the state ('Semashko's model'), and based on three 'cornerstones':

1) qualification

2) accessibility for all

3) free medical care. ${ }^{13}$

But in fact, these principles were just propaganda for earning political points and the people's support, and in reality were used to justify the class-based character of medical assistance, which was expressed in providing medical care for workers and peasants first. All private, insurance and charitable medical institutions were nationalised, and put under the control of the state.

The centre of Soviet medicine was the People's Commissariat for Health Care, which was created in Moscow on 18 July $1918 .{ }^{14}$ In the regions, the Commissariat for Health Care was provided by provincial, district and city health departments, which answered to the Commissariat for Health Care and local executive committees. Afterwards, most health-care commissariats of Soviet republics were built on the example of the RSFSR. ${ }^{15}$

${ }^{11}$ Bor'ba za sovetskuiu vlast'v Belorussii, p. 40

${ }^{12}$ Ibid.

${ }^{13}$ Meditsina proshlogo i meditsina budushhego (Yaroslavl, 1919), p. 11; Protokoly $i$ stenograficheskie otchety sezdov i konferentsij Kommunisticheskoi Partii Sovetskogo Soiuza. Vos'moi sezd RKP(b). Protokoly (Moskva, 1959), p. 411.

${ }^{14}$ Izvestiia Narodnogo komissariata zdravoohraneniia, Nos 7-8 (1918), p. 2.

${ }^{15}$ Dziarzhaŭny archiŭ Viciebskaj voblasci, col. 64, inv. 1, f. 137, p. 37. 
At the session of the Central Bureau of the Communist Party of Belarus on 15 February 1919, the future LitBel government structure discussed the post of the health-care commissar, which was vacant, with a note 'from the centre', which meant that a candidate would be sent from Moscow later. ${ }^{16}$ Even when the LitBel government started its work, there was no certainty about who would take up the position of health-care commissar. ${ }^{17}$ Vincas Mickevičius-Kapsukas intended the post of health-care commissar for Petras Avižonis, an ophthalmologist, veteran of the Russo-Japanese War and the First World War, an experienced physician, doctor of medicine, and well-known journalist, and also an outstanding participant in the Lithuanian revolutionary movement. ${ }^{18}$

By 1919, Avižonis had already been head of the Health Department of the Šiauliai Soviet, so Vincas Mickevičius-Kapsukas' choice was quite reasonable. According to archive documents, it is possible to say with a high degree of certainty that, despite calls from Vincas Mickevičius-Kapsukas, Avižonis did not accept the post. ${ }^{19}$ Some researchers believe that he simply refused the offer. ${ }^{20}$ Some claim that he did not consciously turn it down, but simply could not get to Vilnius in the difficult conditions at the beginning of the Polish-Soviet war. ${ }^{21}$

Indirect data indicates that another Lithuanian doctor, Andrius Domaševičius, was appointed to the post of health-care commissar of LitBel, but archive documents confirm that Ilaryjon Puzyroŭ, a former health-care commissar of the Belarusian SSR, in fact became the head of LitBel health-care. Later, he would be formally replaced by the doctor Vladimir Lenski, but in fact, Puzyroŭ continued to run the Commissariat until the summer of 1919 (most Health Care Commissariat orders from March to May 1919

\footnotetext{
${ }^{16}$ Nacyjanal'ny archiŭ Respubliki Bielarus' (henceforth - NARB), c. 4p, inv. 1, f. 8, p. 34 .

${ }^{17}$ Bor'ba za sovetskuiu vlast'v Belorussii, p. 38 .

${ }^{18}$ V. Sjudikas, B. Kalnin, 'Oftal'molog P. Avižonis - vospitannik Tartuskogo universiteta', in: Tartu Ülikooli Ajaloo Küsimusi, Vol. VI (1977), pp. 86-97.

${ }^{19}$ NARB, c. 4p, inv. 1, f. 32, p. 10.

${ }^{20}$ A. Gaigalaitè, 'Petras Avižonis', in: Žiemgala, No 1 (1998), pp. 15-18.

${ }^{21}$ Sjudikas, Kalnin, 'Oftal'molog P. Avižonis', p. 95.
} 
were signed by him). ${ }^{22}$ Puzyroŭ did not have even a basic medical education (regular practice in Soviet states in 1920-1930), but due to a lack of personnel, he was the only experienced administrator who agreed to run LitBel health-care. It seems there were very few medical specialists in Vilnius who agreed to collaborate with the Bolsheviks. This is confirmed by the fact of the relocation of most former Belarusian SSR Health Care Commissariat staff from Minsk to Vilnius for the formation of the LitBel Commissariat at the beginning of March 1919. ${ }^{23}$

\section{The medical policy of the LitBel Commissariat for Health Care}

According to basic Soviet medical policy, Ilaryjon Puzyroŭ, the actual head of the LitBel People's Commissariat for Health Care, vigorously pursued a course of nationalisation of medical resources, primarily medicines, which had already largely been carried out in Belarus, and to a lesser extent in Lithuania. ${ }^{24}$ However, the initial nationalisation of medicines was dictated not only by Bolshevik policy, but also by urgent need: at the beginning of the Polish offensive, the Belarusian and Lithuanian lands faced a large wave of infectious diseases (especially typhus, cholera and dysentery), which complicated the situation in LitBel. To combat the infections, on 2 April 1919, the LitBel government decided to build a network of public baths and organised sanitary squads, for which 500 ,ooo roubles was allocated. ${ }^{25}$

Despite these measures, the Health Care Commissariat's antiepidemic capacity was very weak, even in the nominal capital of LitBel. According to Polish local sanitary reports, during the Soviet occupation of Vilnius (January to April 1919), 'pollution

${ }^{22}$ I. Pantjiuk, 'Ministry zdravoohraneniia Belarusi: 1919-2011 gg.', in: Sovremennaia stomatologiia, No 1 (2012), p. 78; G. Krjuchok, 'Sozdanie Narodnogo komissariata zdravookhraneniia BSSR i ego nachal'naia deiatel'nost' v 1919 g.', in: Sborniknauchnyh trudov (kafedry obshchestvennykh nauk), Vol. 22 (1958), p. 185.

${ }^{23}$ NARB, c. 8o8, inv. 1, f. 4, p. 39.

${ }^{24}$ NARB, c. 4 p, inv. 1, f. 32, p. 18.

${ }^{25}$ E. Shkljar, Bor'ba trudiashchikhsia Litovsko-Belorusskoi SSR, p. 61. 
in the city reached ... unheard-of proportions', which caused widespread infections ('entire neighbourhoods were full of patients with typhus'). ${ }^{26}$

However, the People's Commissariat for Health Care did not have time to organise anti-epidemic measures: due to the advance of the Polish army and the Bolshevik withdrawal from Vilnius the LitBel government moved to Dvinsk (Daugavpils) on 21 April 1919, and later to Minsk on 28 April. ${ }^{27}$

It should be noted that after its arrival in Minsk, the LitBel People's Commissariats did not create new frameworks, but incorporated the corresponding institutions of the Minsk Provincial Revolutionary Committee into their structure..$^{28}$ The People's Commissariat for Health Care was no exception, and was reorganised on 30 April 1919, on the basis of the Minsk Provincial Medical Sanitary Department, with the transfer of its departments into the corresponding structures of the People's Commissariat for Health Care, and sections into sub-departments. ${ }^{29}$

Despite the desperate position of LitBel, the formal realisation of Soviet policy in medicine continued. As part of the implementation of the Soviet health-care model, it was envisaged to abolish the pre-revolutionary model of medicine. Therefore, from 9 May 1919, by order of the LitBel People's Commissariat for Health Care, all medical institutions were renamed from 'Zemski' to 'Sovietski', which certainly did not reflect any changes, but was supposed to instill confidence in the irreversible Bolshevik transformations for the benefit of the workers and peasants..$^{30}$

One truly useful measure taken by the People's Commissariat for Health Care was the activation of the fight against epidemics: order No 5 of 10 May 1919 authorised the creation of new sanitary and epidemic squads, which not only fought infections but also provided the population with all possible medical care. ${ }^{31}$

${ }^{26}$ Lietuvos centrinis valstybès archyvas, f. 64, ap. 20, b. 25, l. 68.

${ }^{27}$ E. Shkljar, Bor'ba trudiashchikhsia Litovsko-Belorusskoi SSR, p. 103; A. Cichamiraŭ, 'Litoŭska-Bielaruskaja Savieckaja Sacyjalistychnaja Respublika', p. 383 .

${ }^{28}$ NARB, c. 8 o8, inv. 1, f. 4, p. 82.

${ }^{29}$ Organy gosudarstvennoi vlasti, p. 231.

${ }^{30}$ NARB, c. 8 o8, inv. 1, f. 4 , p. 88.

${ }^{31}$ Ibid., p. 89 . 
However, the real situation in medicine only worsened, and all innovations were dictated by wartime requirements only. Due to the continuation of the Polish-Soviet war, civil and military health care ceased to be separate. On 22 May 1919, the LitBel Council of Defence put all civilian medical institutions under military-medical rule, and all medical personnel were conscripted into military service. From that moment on, no medical employee had the right to leave their place of residence and work without the permission of the People's Commissariat for Health Care or its local departments. ${ }^{32}$ It should be noted that during warfare, civilian doctors had to work 16 hours a day under conditions of declared labour conscription, while their remuneration did not meet their basic living requirements. ${ }^{33}$

The further advance of Polish troops led to the decision to move government agencies away from Minsk, so on 24 May 1919, the LitBel People's Commissariat for Health Care was evacuated to Bobruisk, while most hospitals were immediately sent to Smolensk, as far from the front as possible. ${ }^{34}$

The structure of the first Soviet commissariats often changed, amid the constant military danger and the emergence of new challenges. The People's Commissariat for Health Care was no exception, and after the evacuation it divided into two parts:

1) the 'field office', which remained in Minsk and dealt with the needs of the front, the evacuation of medical institutions, and stocks of medicines;

2) the Commissariat, which operated in Bobruisk, and conducted the main work.

Thus, the main centre for the development of LitBel medicine moved to Bobruisk. The relatively 'calm' situation in conditions far from the front line made it possible to carry out effective work, create a fully fledged structure of sub-departments of the People's Commissariat for Health Care, and optimise the activities of medical institutions at the district level. At its peak, the LitBel

\footnotetext{
${ }^{32}$ Zvezda, No 445 (1919), p. 4.

${ }^{33}$ Dziarhaŭny archiŭ Homiel'skaj voblasci, c. 11, inv. 1, f. 757, p. 94.

${ }^{34}$ Istoriia gosudarstva i prava Belorusskoi SSR, pp. 46, 86.
} 


\section{People's Commissariat for Health Care consisted of 12 departments with 42 sub-divisions and one section, with a total of 163 staff units (Fig. 1). ${ }^{35}$}

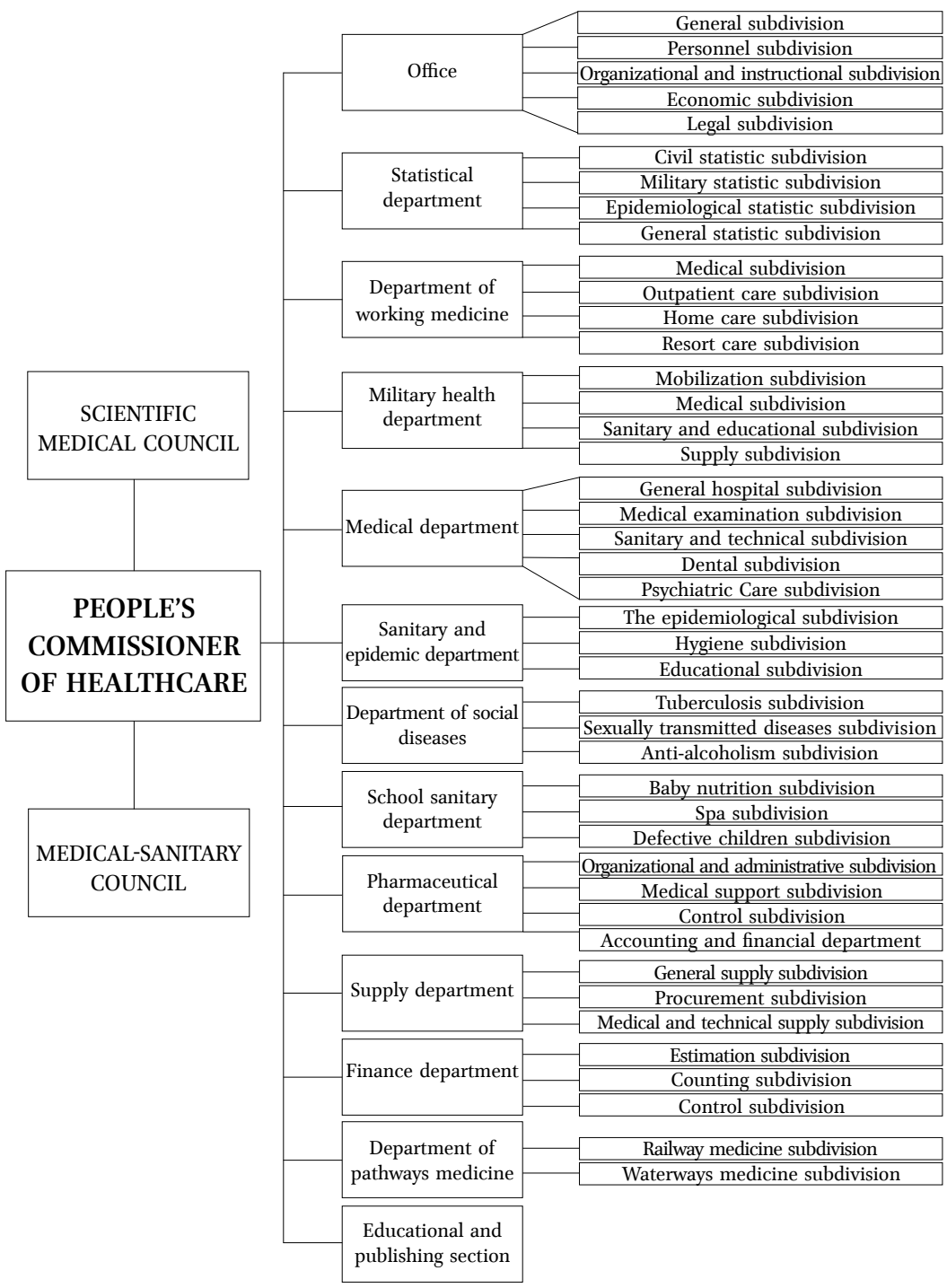

Figure 1. The structure of the People's Commissariat for Health Care of the SSR of Lithuania and Belarus in 1919.

${ }^{35}$ G. Krjuchok, 'Sozdanie Narodnogo komissariata zdravookhranenija BSSR', p. 187. 
However, the Polish occupation of most of LitBel until the summer of 1919 determined the liquidation of its institutions, which began with the reduction of the apparatus of the People's Commissariats to $20 \%$ of the state. The People's Commissariats of LitBel were gradually turned into divisions of the Minsk Provincial Revolutionary Committee, which took over the functions of the LitBel government from 19 July $1919 .{ }^{36}$

The LitBel People's Commissariat for Health Care formally existed until 25 July 1919, when, along with the other commissariats of the Republic, it was renamed a Department of the Minsk Provincial Revolutionary Committee. ${ }^{37}$ Despite the title, it was located in Bobruisk, and declared itself to be the government of unoccupied LitBel. ${ }^{8}$ The continuity in the formation of the health-care system was underlined by the approval of Ilaryjon Puzyroŭ, the former de facto head of the LitBel Health Care Commissariat, as head of the Health Care Department of the Minsk Provincial Revolutionary Committee on 5 August 1919. ${ }^{39}$ Despite the continued formal existence of LitBel until 1920, its government ceased its activities in the summer of 1919, which can be seen in the example of the Health Care Commissariat.

\section{Conclusion}

Despite the formal character of LitBel's existence, several of its bodies showed real activity that was useful to most of the population. The People's Commissariat for Health Care is one of the less studied in the LitBel government. Its organisation and development illustrate the weakness of Soviet rule in Lithuania at the beginning of the Polish-Soviet war. Attempts to realise Soviet health policy were ineffective, determined by the lack of resources and qualified personnel, and the rapidly deteriorating epidemiological situation. Despite the short and mostly formal existence of LitBel, its Commissariat for Health Care tried to prevent epidemics, but

${ }^{36}$ Istoriia gosudarstva i prava Belorusskoi SSR, pp. 46, 90, 91.

${ }^{37}$ Revoliutsionnye komitety BSSR (nojabr' 1918 g. - ijul' 1920 g.). Sbornik dokumentov imaterialov (Minsk, 1961), pp. 176-177.

${ }^{38}$ Istoriia gosudarstva i prava Belorusskoi SSR, p. 92.

${ }^{39}$ Ibid. 
the Polish offensive led to its relocation from Vilnius to Minsk and Bobruisk, and later to the end of LitBel..$^{\circ}$ The relative stability of the Health Care Commissariat in Bobruisk made it possible to create a strong structure and collaboration between its departments, but the Red Army retreat and the occupation of most LitBel territory determined its closure along with the entire LitBel government. Although the activity of the LitBel Commissariat for Health Care was not as effective as the times required, the experience of its existence was a great benefit to the future development of the Belarusian Soviet health-care system during the 1920 .

Author Details

Alexey A. Kapliyev - PhD in history, senior research fellow at the Department of the Modern History of Belarus of the Institute of History of the National Academy of Sciences of Belarus. Research area: history of medicine, organisation of medical assistance to the civilian population during war conflicts, history of Belarus in the interwar period.

Email: kapliyev@gmail.com

\section{Bibliography}

BORIDCZENKO, Stanisław. 'Polityczno-etniczny aspekt kształtowania się wschodnich granic Republiki Białorusi w latach 1918-1924', in: Studia z dziejów Rosji i Europy Środkowo-Wschodniej, Vol. 54, No 2, 2019, pp. 129-149.

CICHAMIRAŬ, Andrej. 'Litoŭska-Bielaruskaia Savieckaya Satsialistychnaia Respublika', in: Entsyklapiediia historii Bielarusi, Vol. 4 (Minsk, 1997).

Dekrety Sovetskoi vlasti. Vol. I. 25 oktiabria 1917 g. - 16 marta 1918 g. (Moskva, 1957).

EIDINTAS, Alfonsas; ŽALYS, Vytautas; SENN, Alfred Erich. Lithuania in European Politics: The Years of the First Republic, 1918-1940, ed. E. Tuskenis (New York, 1998).

GAIGALAITĖ, Aldona. 'Petras Avižonis', in: Žiemgala, No 1, 1998, pp. $15^{-18 .}$

GRITSKEVICH, Anatolii. Zapadnyi front RSFSR 1918-1920. Bor'ba mezhdu Rossiei i Pol'shei za Belorussiiu (Minsk, 2010).

${ }^{40}$ Historical Dictionary of Lithuania, 2nd Edition (Scarecrow Press, 2011), p. 169. 
Historical Dictionary of Lithuania, 2nd Edition (Scarecrow Press, 2011). Istoriia gosudarstva i prava Belorusskoi SSR. Vol. 1: (1917-1936 gg.), ed. S. Margonski et al. (Minsk, 1970).

Izvestiia Narodnogo komissariata zdravookhraneniia, No 7-8, 1918.

Kommunisticheskaia partiia Sovetskogo Soiuza v rezoliutsiiakh i resheniiakh s'ezdov, konferentsii i Plenumov CK (1898-1988). Vol. 2: 1917-1922 gg. I ed. A.G. Egorova, K.M. Bogoliubova (Moskva, 1983).

KRIUCHOK, Grigorii. 'Sozdanie Narodnogo komissariata zdravookhraneniia BSSR i ego nachal'naia deiatel'nost' v 1919 g., in: Sbornik nauchnykh trudov (kafedry obshchestvennykh nauk), Vol. 22, 1958, pp. 180-193.

LAURINAVIČIUS, Česlovas. 'Once Again on Soviet Statehood in Lithuania in 1918-1919', in: Lithuanian Historical Studies, Vol. 13, 2008, pp. 179-19o.

Meditsina proshlogo i meditsina budushchego (Yaroslavl, 1919).

MITSEL'MAKHERIS, Viktoras. Ocherki istorii meditsiny v Litve (Avtoreferat dis. dokt. med. nauk, 1964).

MITSKEVICH-KAPSUKAS, Vintsas. 'Revoliutsiia v Litve (1918 g.) i sozdanie Vremennogo revoliutsionnogo raboche-krest'ianskogo pravitel'stva', in: Istorik-marksist, No 2-3, 1935, pp. 44-52.

Organy gosudarstvennoi vlasti i upravleniia Sovetskoi Belarusi (19171920 gg.): spravochnik, ed. M. Bober et al. (Minsk, 2017).

PANTIUK, Irina. 'Ministry zdravoohraneniia Belarusi: 1919-2011 gg.', in: Sovremennaia stomatologiia, No 1, 2012, pp. 78-83.

PIŁSUDSKI, Józef. Pisma zbiorowe: wydanie prac dotychczas drukiem ogtoszonych. T. VII (Warszawa, 1937).

Protokoly i stenograficheskie otchety sezdov i konferentsii Kommunisticheskoi Partii Sovetskogo Soiuza. Vos'moi s'ezd RKP(b). Protokoly (Moskva, 1959).

Revoliutsionnye komitety BSSR (noiabr' 1918 g. - iiul' 1920 g.). Sbornik dokumentov i materialov (Minsk, 1961).

SHKLJAR, Evgeniia. Bor'ba trudiashchikhsia Litovsko-Belorusskoi SSR $s$ inostrannymi interventami i vnutrennei kontrrevoliuciei (1919-1920 gg.) (Minsk, 1962).

SIUDIKAS, Vytautas; KALNIN, Vadim. 'Oftal'molog P. Avižonis vospitannik Tartuskogo universiteta', in: Tartu Ülikooli Ajaloo Küsimusi VI (Tartu, 1977), pp. 86-97.

VABISHCHEVICH, Aliaksandr, et al. Historyia Bielarusi, Vol. 5: Bielarus' u 1917-1945 hh., ed. M. Kastsiuk (Minsk, 2007).

VAITKEVIČIUS, Bronius. Socialistine revoliucija Lietuvoje 1918-1919 metais (Vilnius, 1967). 
Bor'ba za sovetskuiu vlast'v Belorussii 1918-1920 gg.: Sb. dokumentov $i$ materialov, Vol. 2. Fevral' 1919 g.-1920 g. (Minsk, 1971).

Viestki Chasovaho Rabotnicha-Sielianskaho Radavaho (Sovietskoho) Uradu Bielarusi, No 1, 1919.

Zvezda, 1918-1919.

\title{
LIETUVOS IR BALTARUSIJOS SOVIETŲ SOCIALISTINĖS RESPUBLIKOS VALDŽIOS KŪRIMAS SEKANT SVEIKATOS APSAUGOS LIAUDIES KOMISARIATO ORGANIZAVIMO PAVYZDŽIU 1919 M. PRADŽIOJE
}

Santrauka

\author{
ALEXEY A. KAPLIYEV
}

Sveikatos apsaugos sistemos organizavimo klausimas ankstyvosiose sovietinėse respublikose yra retai studijuojamas naujausių laikų istorijos aspektas. Nors formaliai egzistavo Lietuvos ir Baltarusijos Sovietų Socialistinè Respublika, jos valdžia turëjo spręsti realiai iškilusias problemas smarkiai blogėjančios epidemiologinės situacijos sąlygomis, ir tai vertẻ steigti specialią aukšto lygio medicininę instituciją. Siekdamas sukurti klasine teorija paremtą sovietinę sveikatos apsaugos sistemą, Litbelo sveikatos apsaugos liaudies komisariatas vis dèlto nesulaukè pakankamai išteklių ar vietinio medicininio personalo paramos, dèl to jo darbas nebuvo efektyvus. Dèl prasidèjusio Sovietų Rusijos ir Lenkijos karo Raudonoji armija pasitraukè iš Lietuvos, o Litbelo valdžios įstaigos buvo perkeltos iš Vilniaus į Minską, vèliau ị Bobruiską, kur galiausiai buvo sukurta Sveikatos apsaugos komisariato struktūra. Tačiau dèl Lenkijos kontrpuolimo Litbelas buvo likviduotas, o kartu su juo baigẻ savo veiklą ir Sveikatos apsaugos liaudies komisariatas. 